\title{
Bioavailability of Soy Protein and Corn Zein Films
}

\author{
Laura B. Matthews', M. Elizabeth Kunkel' ${ }^{1}$, James C. Acton¹, Amod A. Ogale², Paul L. Dawson ${ }^{1}$ \\ ${ }^{1}$ Department of Food Science and Human Nutrition, Clemson University, Clemson, USA; ${ }^{2}$ Department of Chemical Engineering, \\ Clemson University, Clemson, USA. \\ Email: pdawson@clemson.edu
}

Received July $24^{\text {th }}, 2011$; revised October $11^{\text {th }}$, 2011; accepted October $19^{\text {th }}, 2011$.

\begin{abstract}
The in vivo bioavailability of soy protein isolates and corn zein film material before and after film formation by heat/ pressure was determined. The in vitro digestibility of corn zein before and after film formation was also measured. Films were produced from anhydrous protein with $30 \%$ glycerol added using a heat-press method with no use of casting solvents or cross-linking agents. Corn zein raw and film material were ground under liquid nitrogen then digested in two enzyme-acid cocktails with free amino acid analysis before and after digestion. The protein efficiency ratio and net protein ratio were determined for both zein and soy protein using a weanling Sprague-Dawley descended rat feeding study. The in vitro digestibility study indicated that the non-heat pressed corn zein was more digestible than the heat pressed zein. However, the in vivo results indicated that corn and soy protein were equally bioavailable whether they were derived from film mixture prior to or after film formation. Both corn zein and soy protein material had lower protein efficiency ratio than the control diet. Furthermore, soy protein films materials had a higher protein efficiency ratio than corn zein.
\end{abstract}

Keywords: Bioavailability, Bio-Based Films, Edible Films, Protein Digestibility, Packaging

\section{Introduction}

With increased public environmental consciousness, the interest in bio-based packaging has increased. Packaging materials that are produced from renewable resources that can biodegrade after disposal and that can be utilized by plants and animals as nutrients are one solution to solid waste disposal to minimize the environmental impact of packaging. Films produced from food proteins are one type of bio-based packaging that reduces the usage of other natural resources. Protein films can be created from casein, collagen, corn zein, gelatin, soy protein isolate, wheat gluten and other food proteins [1,2]. Edible protein films not only decrease environmental pollution, but can also enhance food properties such as flavour, appearance and nutritional value through natural additives or through inherent protein properties imparted to the film [3]. Protein films can carry antimicrobials, antioxidants, and scavengers to prevent food spoilage and increase food safety.

In this study, the bioavailability of heat-set protein films was measured. Heat-set protein films were developed from corn zein and soy protein isolate [4]. Corn zein films form tough, glossy, hard grease-proof coatings. Currently corn zein is used to coat nuts and confectionery items [5]. Soy protein isolate films aid in cohesiveness, adhesiveness, water and fat absorption and emulsification [3]. Soy protein has been shown to improve batter adhesion and reduce moisture migration in raisins and dried peas [6-9]. In addition to current applications, new and expanded areas for bio-based films and coatings are of interest in the "Green" movement, including recycling packaging as animal and plant food.

Protein quality of edible films can be determined by various methods including in vitro and in vivo assays. The in vitro assay can determine protein digestibility and estimate the availability of amino acids [10] (AOAC, 1984) and is less time consuming and costly than in vivo assays. In vivo assays of protein quality examine the relationship between nitrogen intake and change in body nitrogen or some correlate of body nitrogen. Animal bioassays are frequently expressed as protein efficiency ratio (PER), net protein ratio (NPR), biological value (BV), and net protein utilization (NPU). The PER is the official method for determining protein quality in the United States and Canada as well as the official method for measurement of protein quality for nutritional labeling [10,11].

Many edible protein films are produced by casting. In casting corn zein films, the protein film is formed by 
suspending the zein in an ethyl alcohol solution followed by drying on a flat, non-porous surface [3]. Aqueous solutions of soy protein isolate (SPI) can also form films on stainless steel plates at high temperatures. Both the corn zein and the SPI will undergo phase changes due to a denaturation of the protein during film formation. Zein resin can be prepared for heat extrusion by mixing with long chain fatty acids followed by precipitation in water [12] and heat-extruded soy protein films can be prepared by adding cross-linking agents. In the current study, no cross-linking agents were added nor resin prepared prior to film formation and the proteins films were formed from directly from a mixture of a dry powder and a plasticizer combined under heat and pressure.

Heat denatures proteins by breaking weak interactions and interfering with hydrophobic interactions. This causes the protein to unfold from its native tertiary structure exposing reactive amino acid side groups. Denaturation can increase digestibility of protein by opening the tertiary and secondary structure facilitating digestion. In creating protein films, the native protein structure unfolds then reforms into more linear chains that form a film structure. Thus creating films from proteins may alter the digestibility or bioavailability of the protein. In light of this, the objective of this research was to determine if the formation of soy and corn protein based biodegradable packaging material affected the materials protein bioavailability.

\section{Materials and Methods}

\subsection{Materials}

ANRC Reference Protein, (ICN Biomedicals, Inc., Cleveland, OH); F-4000 Regular Grade, (Freeman Industries, Tuckahoe, NY); Supro 620 Isolated Soy Protein, (Protein Technologies International, St. Louis, MO); Alphacel Non Nutritive Bulk, (ICN Biochemicals division of ICN Biomedicals, Inc., Cleveland, OH); Pure Vegetable Oil, (Bi-Lo, Inc., Mauldin, SC); AIN Vitamin Mixture 76, (ICN Biomedicals, Inc., Cleveland, OH), [containing (per kg mixture): thiamine hydrochloride, $600.0 \mathrm{mg}$; riboflavin, $600.0 \mathrm{mg}$; pyridoxine hydrochloride, $700.0 \mathrm{mg}$; nicotinic acid, $3.0 \mathrm{~g}$; D-calcium pantothenate, $1.6 \mathrm{~g}$; folic acid, 200.0 mg; D-biotin, $20.0 \mathrm{mg}$; cyanocobalamin (Vitamin B-12), $1.0 \mathrm{mg}$; retinyl palmitate (Vitamin A), $1.6 \mathrm{~g}$ (250,000 IU/g); DL-alpha-tocopherol acetate, $20.0 \mathrm{~g}$ (250 $\mathrm{IU} / \mathrm{g})$; cholecalciferol (Vit $\left.\mathrm{D}_{3}\right), 250.0 \mathrm{mg}$ (400,000 IU/g); menaquinone (Vitamin K), $5.0 \mathrm{mg}$; sucrose, finely powdered, 972.9 g]; AIN 76 Mineral Mix, (ICN Biomedicals, Inc., Cleveland, $\mathrm{OH})$, containing [(g/kg mixture): calcium phosphate dibasic, $500.00 \mathrm{~g}$; sodium chloride, 74.00 g; potassium citrate monohydrate, 222.00 g; potassium sulfate, $52.00 \mathrm{~g}$; magnesium oxide, $24.00 \mathrm{~g}$; mana- gnous carbonate $(43 \%$ - $48 \% \mathrm{Mn}), 3.50 \mathrm{~g}$; ferric citrate (16\% - 17\% Fe), $6.00 \mathrm{~g}$; zinc carbonate (70\% ZnO), 1.60 g; cupric carbonate $(53 \%-55 \% \mathrm{Cu}), 0.30 \mathrm{~g}$; potassium iodate, $0.01 \mathrm{~g}$; sodium selenite, $0.01 \mathrm{~g}$; chromium potassium sulfate, $0.55 \mathrm{~g}$; sucrose, finely powdered, $118.00 \mathrm{~g}$; pure cane sugar, (Dixie Crystals Brand, Inc., Savannah, GA); corn starch, (ICN Biomedicals, Inc., Cleveland, $\mathrm{OH}$ ); choline chloride, (J.T. Baker Chemical Co., Phillipsburg, NJ).

\subsection{Film Formation}

The protein films were formed using a heat-set method described in an earlier study [4]. A protein mixture consisting of 70\% protein (corn zein, F-4000 Regular Grade, Freeman Industries, Inc., Tuckahoe, NY or soy protein isolate, SUPRO ${ }^{\circledR} 620$, Protein Technologies International, St. Louis, MO) and 30\% plasticizer (glycerin) was mixed with a mortar and pestle and dispersed onto a $7 \times 7$ inch aluminum plate (2.0 g of SPI; $3.5 \mathrm{~g}$ of zein). Another aluminum plate was placed atop the bottom plate then the aluminum plate sandwich containing the film mixture was pressed using a press (model 2629, Carver Inc., 1569 Morris Rd. Wabash, IN). The platens were closed under a force of $66 \mathrm{kN}$ for 2 minutes at $150 \mathrm{C}$. After cooling in air for 2 minutes the film was peeled from the aluminum plate and held in plastic bags until needed. The prepared protein films were placed in a stainless steel container. Liquid nitrogen was poured onto the films. They were crushed using a mortar and pestle and then ground using an blender (Osterizer, Oster Corp., Milwaukee, WI).

\subsection{In Vitro Protein Digestibility}

In vitro protein digestion was performed on the corn zein films and corn zein powder [10]. Two enzyme cocktails containing intestinal enzymes were used to digest the test proteins. Solution A contained trypsin, chymotrypsin, and peptidase, and Solution B contained bacterial protease. Samples $(0.5 \mathrm{ml})$ were taken at times $0,5,10,15$, and 20 minutes for gel electrophoresis. Samples $(0.5 \mathrm{ml})$ of each enzyme cocktail were also retained for this purpose. Free amino acid analysis was performed on samples taken before and immediately following the protein digestion. The final $\mathrm{pH}$ of the protein solution was used to determine the percent digestibility of the protein using the following formula:

$$
\text { \% Digestibility = } 234.84-22.56(\mathrm{X}) \text {, }
$$

where $\mathrm{X}=$ final $\mathrm{pH}$.

\subsection{Nitrogen Determination}

A micro-Kjeldahl method was employed to determine nitrogen content of film materials. The digestion procedure involves the reaction of hot sulfuric acid with or- 
ganic materials. A catalyst containing $\mathrm{K}_{2} \mathrm{SO}_{4}$ and $\mathrm{CuSO}_{4}$ and an oxidizing agent (sulfuric acid, $\mathrm{H}_{2} \mathrm{SO}_{4}$ ) breaks down the organic matter into $\mathrm{CO}_{2}, \mathrm{H}_{2} \mathrm{O}$ and $\mathrm{NH}_{3}$. From there, the sample is boiled for a period of time in order to break down the intermediate compounds formed during the early stages of digestion. These compounds are more resistant to decomposition than the parent compound. They must be kept at or near the decomposition point of the intermediate for an extended period of time for thermal decomposition to occur. The distillation procedure involves the recovery and determination of nitrogen as ammonia. The most common method is heat distillation. Sodium hydroxide $(\mathrm{NaOH})$ is slowly added to the digest. The heat of the reaction of the sulfuric acid and sodium hydroxide is great enough to cause the loss of ammonia. The ammonia is collected in an absorbing liquid (Boric acid) and the amount of nitrogen is measured by back titration with hydrochloric acid $(\mathrm{HCl})$.

\subsection{Gel Electrophoresis}

Gel electrophoresis of the samples from the different digestion times were used to determine the amount of protein degradation over time. Sodium dodecyl sulfate polyacrylamide gel electrophoresis (SDS-PAGE) was used to separate the protein subunits of each in vitro sample. Ready Gels ${ }^{\mathrm{TM}}$ for the Mini-PROTEAN ${ }^{\circledR}$ II Cell (Bio-Rad Laboratories, Hercules, CA, 94547) containing $10 \%$ - 20\% TrisGlycine with 4\% stacking gel, $\mathrm{pH} 8.8$ were used as the standard gel. The gels were stored at $4^{\circ} \mathrm{C}$ prior to use. Each timed sample from the in vitro digestion was combined with $0.5 \mathrm{ml} / \mathrm{ml}$ SDS reducing buffer containing bromophenol blue tracking dye. Samples were then placed in a boiling water bath for $10 \mathrm{~min}$ utes. Ten microliters of each sample and 10 microliters of each enzyme cocktail were applied to the Ready $\mathrm{Gel}^{\mathrm{TM}}$. After electrophoresis, gels were stained with Bio-Rad Silver Stain (Bio-Rad Laboratories, Hercules, CA, 94547). Molecular weights of the fractions were estimated using the following known molecular weight standards: Broad Range SDS-PAGE Molecular Weight Standards (BioRad Laboratories, Hercules, CA, 94547), Insulin, and a protein standard.

\subsection{Amino Acid Analysis}

Free amino acid analyses were performed on samples before and after in vitro digestion. The samples were subjected to acid hydrolysis [13]. Under these conditions, three amino acids are largely destroyed (tryptophan, cyst(e)ine, and methionine). These amino acids are recovered through basic hydrolysis to recover tryptophan [14] and performic acid oxidation to recover cyst(e)ine and methionine [15]. Sample analysis was performed on a Dionex 2000I amino acid analyzer with a polystyrene sulfonic acid resin column and ninhydrin detection system.

\subsection{In Vivo Protein Analysis}

The availability and digestibility of the protein in the protein films were determined by in vivo methods using Sprague Dawley descended male rats. The rats were fed nutritionally adequate diets containing $10 \%$ protein (Table 1). The protein sources were all from a single source. Food intake, weight gain, and faecal output data were collected. Nitrogen analysis on the feces was performed. PER and NPR were calculated using these parameters.

\subsection{Protein Efficiency Ratio and Net Protein Ratio Assay}

Sixty male weanling Sprague Dawley descended rats were obtained from Charles Rivers Laboratories (Research Triangle Park, NC). The rats were fed a control mixture containing $10 \%$ protein from casein for an adaptation period of 3 days. The rats were then grouped into 6 groups of 10 rats each on the basis of equal mean body weights $(58.3 \pm 0.5 \mathrm{~g})$. Each group was assigned one of the six dietary regimens: protein-free, control, corn zein powder, corn zein film, soy protein powder, and soy protein film. Diet compositions can be found in Table 1. The experiment followed a completely random design with 10 replications per treatment. The rats were individually housed in wire-bottom cages and given food and distilled deionized water adlibitum. The environment was maintained at $72 \mathrm{~F}, 50 \% \pm 10 \%$ relative humidity, with a 12-hour light-dark cycle.

At the end of a 10-day period, the group of rats fed the protein-free diet were euthanized. This group of rats was used to determine the net protein ratio. The remaining rats were euthanized at the end of the 28-day period.The rats were weighed bi-weekly and daily feed consumption was corrected for the amount of spilled feed. Faecal output was measured three times a week, dried at approximately $65^{\circ} \mathrm{C}$ for 48 hours, and weighed. Faecal samples were pooled by rat for each of the four weeks. They were then ground using a Waring ${ }^{\circledR}$ blender prior to analysis. The faecal samples were analyzed in duplicate for total nitrogen (zein, SPI and protein free, $\mathrm{N} \times 6.25$; casein control, $\mathrm{N} \times 6.38$ ) by the micro-Kjeldahl method (Labconco 65000 Rapid Distillation Unit, Labconco Corp., Kansas City, MO). The amount of faecal powder used for analysis was $150 \mathrm{mg}$.

PER and NPR were calculated as follows:

$$
\begin{gathered}
\text { PER }=\frac{28 \text { day weight gain }(\mathrm{g})}{28 \text { day protein intake }(\mathrm{g})}, \\
\mathrm{NPR}=\frac{\text { Wt. gain }(\mathrm{g})+\text { Wt. loss on protein-free diet }(\mathrm{g})}{\text { Protein Intake }(\mathrm{g})} .
\end{gathered}
$$


Table 1. Composition of rat diets (amounts in $\mathbf{g} / \mathbf{1 0 0 g})$.

\begin{tabular}{|c|c|c|c|c|c|c|}
\hline Component & Casein $^{\mathrm{a}}$ & Corn Zein ${ }^{\mathrm{b}}$ Powder & Corn Zein ${ }^{\mathrm{b}}$ Film & Soy Protein ${ }^{\mathrm{c}}$ Powder & Soy Protein ${ }^{c}$ Film & Protein-Free \\
\hline Protein & 11.23 & 15.87 & 15.87 & 15.87 & 15.87 & - \\
\hline Cellulose $^{\mathrm{d}}$ & 3.00 & 3.00 & 3.00 & 3.00 & 3.00 & 3.00 \\
\hline $\mathrm{Oil}^{\mathrm{e}}$ & 8.00 & 8.00 & 8.00 & 8.00 & 8.00 & 8.00 \\
\hline Vitamin $\mathrm{Mix}^{\mathrm{f}}$ & 1.00 & 1.00 & 1.00 & 1.00 & 1.00 & 1.00 \\
\hline Mineral Mix ${ }^{\mathrm{g}}$ & 3.50 & 3.50 & 3.50 & 3.50 & 3.50 & 3.50 \\
\hline Sucrose $^{\mathrm{h}}$ & 58.07 & 53.43 & 53.43 & 53.43 & 53.43 & 69.30 \\
\hline Starch $^{\mathrm{i}}$ & 15.00 & 15.00 & 15.00 & 15.00 & 15.00 & 15.00 \\
\hline Choline $^{\mathrm{j}}$ & 0.20 & 0.20 & 0.20 & 0.20 & 0.20 & 0.20 \\
\hline
\end{tabular}

${ }^{\mathrm{a}}$ ANRC Reference Protein, ICN Biomedicals, Inc., Cleveland, OH; ${ }^{\mathrm{b}} \mathrm{F}-4000$ Regular Grade, Freeman Industries, Tuckahoe, NY; 'Supro 620 Isolated Soy Protein, Protein Technologies International, St. Louis, MO; ${ }^{\mathrm{d}}$ Alphacel Non Nutritive Bulk, ICN Biochemicals division of ICN Biomedicals, Inc., Cleveland, OH; ${ }^{\mathrm{e}}$ Pure Vegetable Oil, Bi-Lo, Inc., Mauldin, SC; ${ }^{\mathrm{f}} \mathrm{AIN}$ Vitamin Mixture 76, ICN Biomedicals, Inc., Cleveland, OH. Contains (per kg mixture): thiamine hydrochloride, $600.0 \mathrm{mg}$; riboflavin, $600.0 \mathrm{mg}$; pyridoxine hydrochloride, $700.0 \mathrm{mg}$; nicotinic acid, 3.0 g; D-calcium pantothenate, $1.6 \mathrm{~g}$; folic acid, $200.0 \mathrm{mg}$; D-biotin, $20.0 \mathrm{mg}$; cyanocobalamin (Vitamin B-12), $1.0 \mathrm{mg}$; retinyl palmitate (Vitamin A), $1.6 \mathrm{~g}$ (250,000 IU/g); DL-alpha-tocopherol acetate, 20.0 g (250 $\mathrm{IU} / \mathrm{g}$ ); cholecalciferol (Vit $\mathrm{D}_{3}$ ), $250.0 \mathrm{mg}$ (400,000 IU/g); menaquinone (Vitamin K), $5.0 \mathrm{mg}$; sucrose, finely powdered, 972.9 g; ${ }^{\mathrm{g}} \mathrm{AIN} 76 \mathrm{Mineral} \mathrm{Mix,} \mathrm{ICN}$ Biomedicals, Inc., Cleveland, OH. Contains (g/kg mixture): calcium phosphate dibasic, 500.00 g; sodium chloride, 74.00 g; potassium citrate monohydrate, 222.00 g; potassium sulfate, 52.00 g; magnesium oxide, 24.00 g; managnous carbonate (43\% - $48 \% \mathrm{Mn}$ ), 3.50 g; ferric citrate (16\% - $17 \%$ Fe), 6.00 g; zinc carbonate (70\% $\mathrm{ZnO}), 1.60 \mathrm{~g}$; cupric carbonate (53\% - 55\% Cu), 0.30 g; potassium iodate, $0.01 \mathrm{~g}$; sodium selenite, $0.01 \mathrm{~g}$; chromium potassium sulfate, 0.55 g; sucrose, finely powdered, 118.00 g; ${ }^{\text {}}$ Pure cane sugar, Dixie Crystals Brand, Inc., Savannah, GA; ${ }^{i}$ Corn Starch, ICN Biomedicals, Inc., Cleveland, OH; ${ }^{j}$ Choline Chloride, J.T. Baker Chemical Co., Phillipsburg, NJ.

\subsection{Statistical Analysis}

Statistical analysis was performed using the SAS computer software package [16]. The general linear model and paired differences procedures were used to determine the significant differences between rats fed the different diets and among amino acids levels produced in the in vitro digestion. Significance of difference was based on the probability of a Type I error set at the 5\% level.

\section{Results and Discussion}

\subsection{Protein Determination of Corn Zein Films}

The protein content of the corn zein powder was determined to be $87.16 \%$ and the corn zein film contained $63.17 \%$ protein. Amino acid profiles of corn zein powder and corn zein film can be found in Table 2. Corn zein contains extremely small quantities of lysine and tryptophan, the essential amino acids. There are significant differences in the literature values and those found in this study for the amino acids isoleucine and leucine. This may be due to different sources for the raw materials used in the different studies.

\subsection{In Vitro Digestibility}

In vitro digestibility data showed that the digestibilities of corn zein powder and heat-pressed corn zein film were $77.45 \% \pm 1.74 \%$ and $74.51 \% \pm 1.74 \%$, respectively. Free amino acid analysis of both the powder and the film before and after digestion can be found in Table 3 .

In a previous study [17], the protein digestibility of soy protein isolate as $77.4 \% \pm 0.15 \%$.
Table 2. Amino acid analysis of corn zein powder and heatset corn zein film.

\begin{tabular}{lcc}
\hline \multirow{2}{*}{ Amino Acid } & \multicolumn{2}{c}{ g amino acid/100g sample } \\
\cline { 2 - 3 } Essential & Corn Zein Powder & Corn Zein Film \\
Histidine & 1.10 & 0.90 \\
Isoleucine & 3.47 & 2.60 \\
Leucine & 15.94 & 10.31 \\
Lysine & 0.17 & 0.08 \\
Methionine & 1.41 & 2.27 \\
Phenylalanine & 6.18 & 4.55 \\
Threonine & 2.26 & 1.79 \\
Tryptophan & 0.13 & 0.09 \\
Valine & 3.07 & 2.25 \\
Nonessential & & \\
Aspartic Acid & 4.53 & 3.68 \\
Glutamic Acid & 19.97 & 13.25 \\
Serine & 4.13 & 3.07 \\
Proline & 8.70 & 5.92 \\
Glycine & 1.00 & 0.69 \\
Alanine & 8.06 & 5.72 \\
Cystine & 0.78 & 0.63 \\
Tyrosine & 4.32 & 2.82 \\
Arginine & 1.95 & 0.78 \\
Ammonia & & \\
\hline & & \\
\hline
\end{tabular}


Table 3. Free amino acid analysis results of corn zein powder and film before and after in vitro digestion.

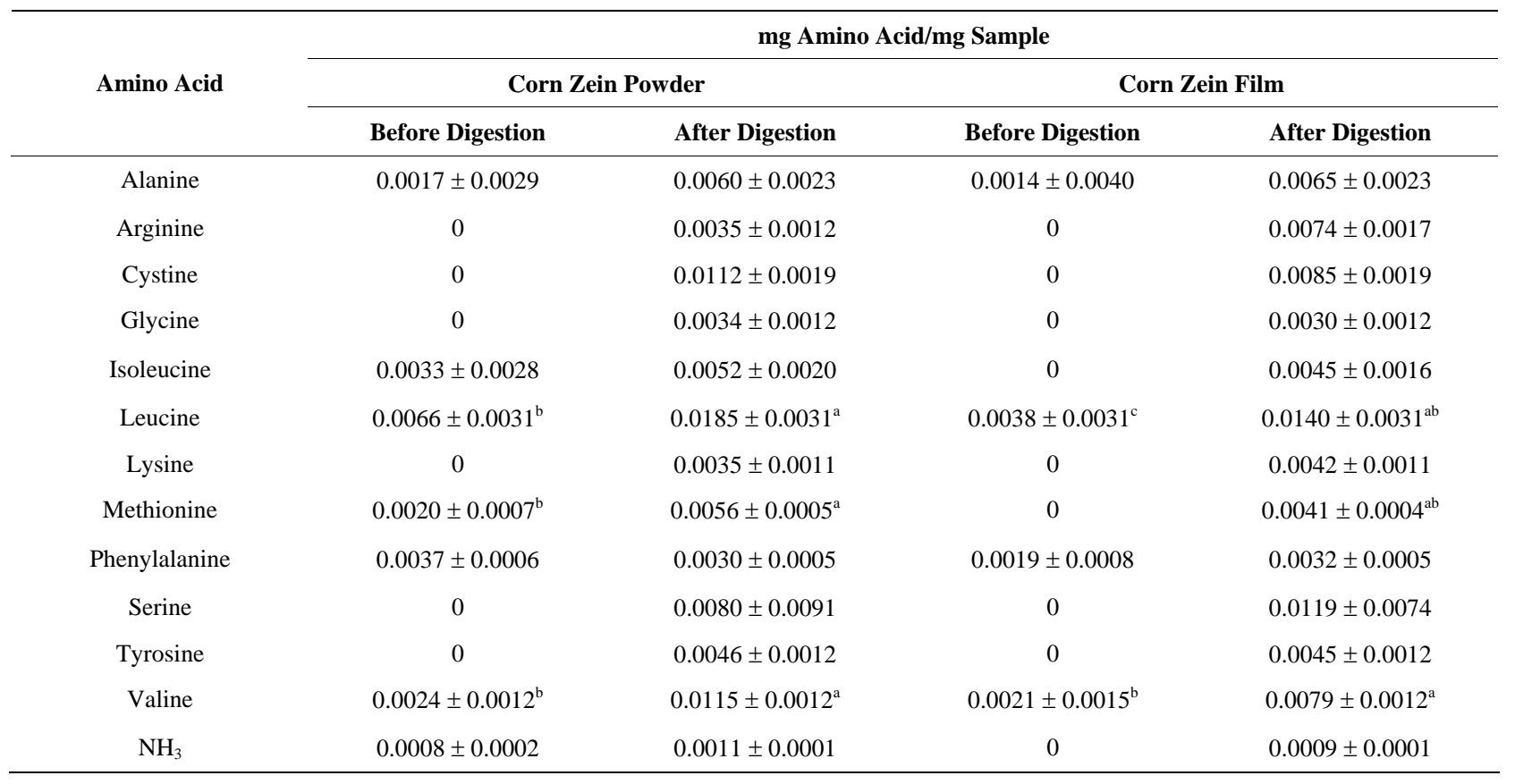

${ }^{\mathrm{a}, \mathrm{b}, \mathrm{c}}$ Means with different superscripts are significantly different $(P<0.05 ; \mathrm{n}=3)$ for each amino acid.

Dietary amino acids are necessary to synthesize protein and other biological molecules by providing nitrogen, energy and essential carbon skeletons. It is therefore necessary to study the amino acid content of any food product in order to understand how it will contribute to the diet. Both the corn zein powder and the heat-set corn zein film in this study released amino acids during digestion. The corn zein powder contains more free amino acids before digestion than the heat-set corn zein film. The protein in the heat-set film may be bound to the plasticizer, thereby tying up some of the potentially free amino acids or possibly may have been degraded via the Maillard reaction during heat-pressing. After digestion the corn zein film breaks down into the same amino acids as the non-heat pressed corn zein powder. This is due to the denaturation of the protein in the heat-set protein film. During denaturation, the protein is broken into peptide fragments. The unfolded protein and peptide fragments offer more locations for enzymatic activity to occur during digestion.

\subsection{Gel Electrophoresis}

Polyacrylamide gel electrophoresis is used to estimate the size of a polypeptide chain by measuring its mobility in the presence of the detergent sodium dodecyl sulfate (SDS). The size of the protein is estimated by its migration through the pores of a continuous gel matrix, where the smaller proteins migrate more rapidly than do large proteins. Protein subunits of samples taken during the in vitro digestion of both corn zein powder and heat-set corn zein film were separated using the SDS-PAGE technique. This procedure showed the increase in digestion into protein subunits over time. Protein-SDS complexes have electrophoretic mobilities through polyacrylamide gels inversely proportional to the logarithm of the length of the polypeptide chain. Using this relationship, the molecular weights of the protein subunits were calculated (Table 4).

During SDS electrophoresis, SDS disrupts and masks properties other than those regarding information dealing with the length of the polypeptide chains. The molecular weight of the unknown polypeptide chain can only be determined to within $10 \%$ of the true value when comparing the mobility of an unknown protein with that of a set of standard marker proteins. Abnormalities in SDS binding or protein conformation, large differences in intrinsic protein charge, and covalently attached nonprotein moieties (especially carbohydrates) can affect the relative mobility of the protein on the gel [18].

\subsection{Protein Efficiency Ratio (PER) and Net Protein Ratio (NPR)}

Protein intake and weight change for each treatment group were monitored over the 28-day period (Figures 1 and 2). Both groups of rats fed corn zein were euthanized at 14 days due to unexpected weight loss greater than $10 \%$ of total body weight and loss of appetite. It is suspected that the rats fed both the corn zein powder diet 
Table 4. Sodium dodecyl sulfate-polyacrylamide gel electrophoresis (sds-page) of corn zein powder and heat-set corn zein film.

\begin{tabular}{|c|c|c|}
\hline Protein & Major Protein Bands & $\begin{array}{c}\text { Estimated Molecular } \\
\text { Weight }\end{array}$ \\
\hline \multirow{6}{*}{$\begin{array}{l}\text { Corn Zein Powder } \\
\qquad(0 \text { min })\end{array}$} & 1 & 64379.86 \\
\hline & 2 & 46547.89 \\
\hline & 3 & 24333.24 \\
\hline & 4 & 21066.87 \\
\hline & 5 & 20321.23 \\
\hline & 6 & 6649.67 \\
\hline \multirow{5}{*}{$\begin{array}{l}\text { Corn Zein Powder } \\
\text { (5 min) }\end{array}$} & 1 & 62101.20 \\
\hline & 2 & 44900.38 \\
\hline & 3 & 24333.24 \\
\hline & 4 & 21066.87 \\
\hline & 5 & 6187.28 \\
\hline \multirow{5}{*}{$\begin{array}{l}\text { Corn Zein Powder } \\
\text { (10 min) }\end{array}$} & 1 & 62101.20 \\
\hline & 2 & 44900.38 \\
\hline & 3 & 24333.24 \\
\hline & 4 & 21066.87 \\
\hline & 5 & 6414.31 \\
\hline \multirow{6}{*}{$\begin{array}{l}\text { Corn Zein Powder } \\
\text { (15 min) }\end{array}$} & 1 & 62101.20 \\
\hline & 2 & 44900.38 \\
\hline & 3 & 24333.24 \\
\hline & 4 & 21066.87 \\
\hline & 5 & 18908.19 \\
\hline & 6 & 6649.67 \\
\hline \multirow{6}{*}{$\begin{array}{l}\text { Corn Zein Powder } \\
\text { (20 min) }\end{array}$} & 1 & 62101.20 \\
\hline & 2 & 44900.38 \\
\hline & 3 & 24333.24 \\
\hline & 4 & 19601.98 \\
\hline & 5 & 18238.96 \\
\hline & 6 & 6649.67 \\
\hline \multirow{7}{*}{$\begin{array}{l}\text { Corn Zein Film } \\
\quad(0 \text { min })\end{array}$} & 1 & 57782.99 \\
\hline & 2 & 41778.23 \\
\hline & 3 & 24333.24 \\
\hline & 4 & 21066.87 \\
\hline & 5 & 10247.08 \\
\hline & 6 & 7962.51 \\
\hline & 7 & 6187.28 \\
\hline
\end{tabular}

\begin{tabular}{|c|c|c|}
\hline \multirow{7}{*}{$\begin{array}{l}\text { Corn Zein Film } \\
\qquad(5 \mathrm{~min})\end{array}$} & 1 & 57782.99 \\
\hline & 2 & 40691.15 \\
\hline & 3 & 24333.24 \\
\hline & 4 & 21066.87 \\
\hline & 5 & 10247.08 \\
\hline & 6 & 8254.68 \\
\hline & 7 & 6649.67 \\
\hline \multirow{6}{*}{$\begin{array}{l}\text { Corn Zein Film } \\
\qquad(10 \mathrm{~min})\end{array}$} & 1 & 57782.99 \\
\hline & 2 & 40691.15 \\
\hline & 3 & 24333.24 \\
\hline & 4 & 21066.87 \\
\hline & 5 & 7680.69 \\
\hline & 6 & 6649.67 \\
\hline \multirow{7}{*}{$\begin{array}{l}\text { Corn Zein Film } \\
\quad(15 \text { min })\end{array}$} & 1 & 57782.99 \\
\hline & 2 & 40691.15 \\
\hline & 3 & 24333.24 \\
\hline & 4 & 21066.87 \\
\hline & 5 & 7680.69 \\
\hline & 6 & 5757.05 \\
\hline & 7 & 4984.25 \\
\hline \multirow{5}{*}{$\begin{array}{l}\text { Corn Zein Film } \\
\text { (20 min) }\end{array}$} & 1 & 24333.24 \\
\hline & 2 & 21066.87 \\
\hline & 3 & 10247.08 \\
\hline & 4 & 6649.67 \\
\hline & 5 & 4984.25 \\
\hline \multirow{5}{*}{ Enzyme A } & 1 & 26151.70 \\
\hline & 2 & 22877.05 \\
\hline & 3 & 8254.68 \\
\hline & 4 & 6893.66 \\
\hline & 5 & 4473.53 \\
\hline \multirow{4}{*}{ Enzyme B } & 1 & 7680.69 \\
\hline & 2 & 6414.31 \\
\hline & 3 & 6187.28 \\
\hline & 4 & 4984.25 \\
\hline
\end{tabular}

and the heat-set corn zein film diet either found the taste of the corn zein unpalatable or that an imbalance in the amino acid ratio reduce feed intake causing a loss of weight. Rats fed the soy protein isolate diets and the control diet gained weight at a steady pace throughout the 


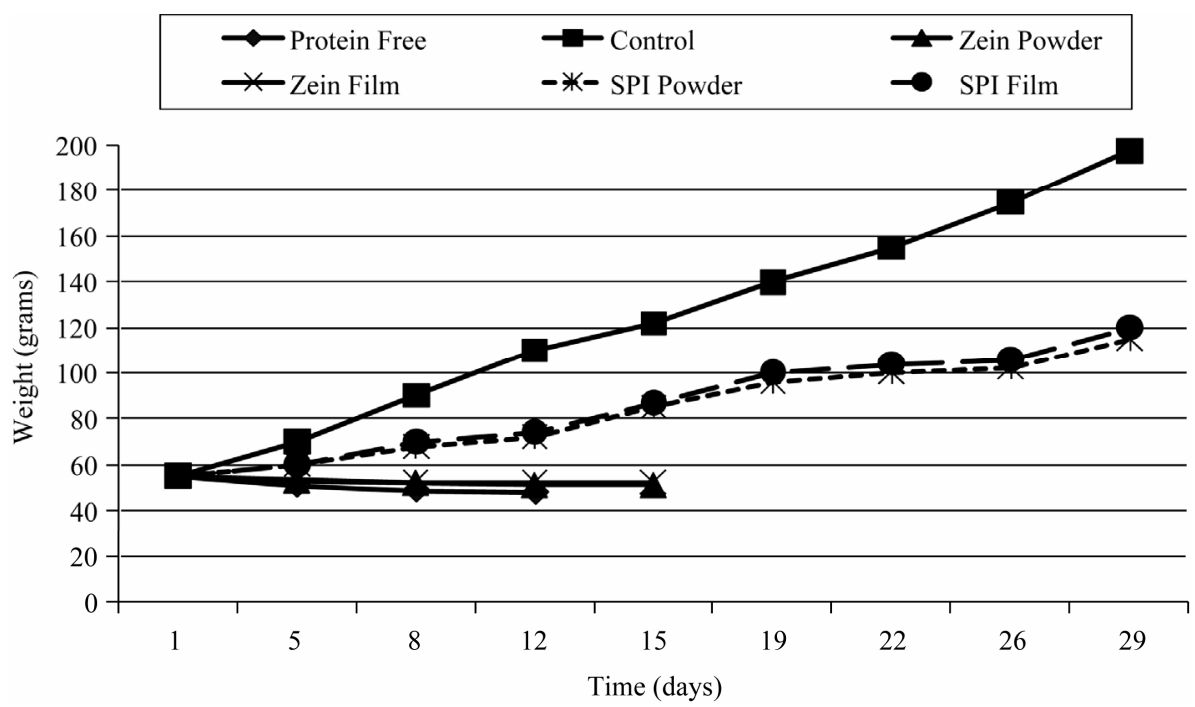

Figure 1. Average weight during the feeding period of Sprague Dawley rats fed a protein free diet (protein free) or nutritionally adequate diets containing; casein (control), corn zein powder (zein powder), ground corn zein from heat-pressed films (zein film), soy protein isolate powder (SPI powder), and ground soy protein isolate from heat-pressed films (SPI film).

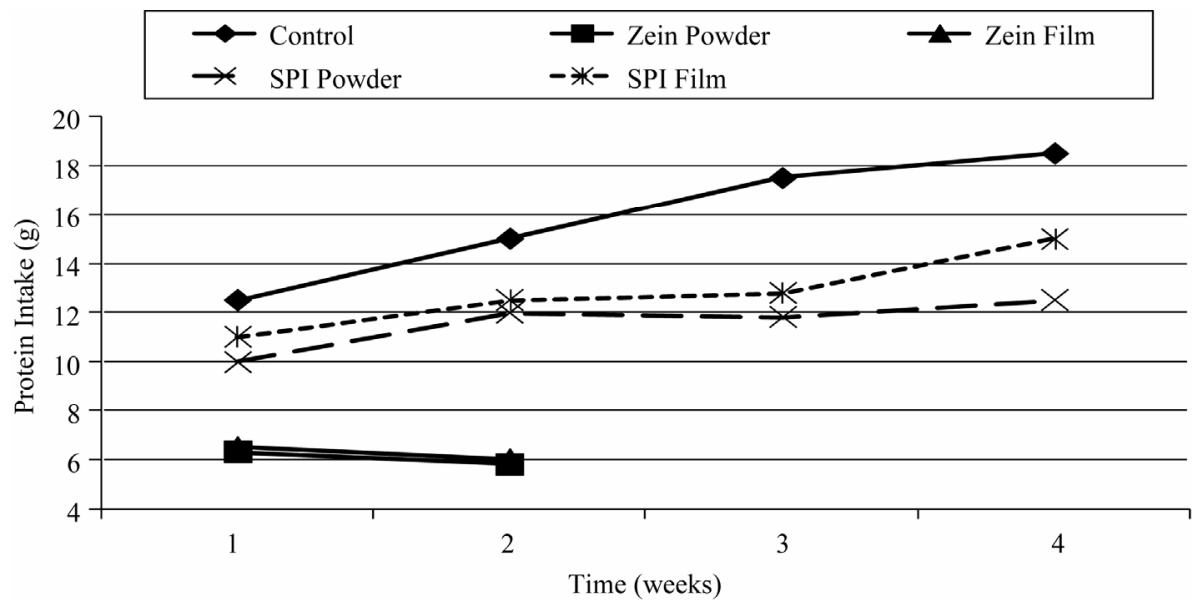

Figure 2. Average weekly protein intake of Sprague Dawley rats fed a nutritionally adequate diets containing; casein (control), corn zein powder (zein powder), ground corn zein from heat-pressed films (zein film), soy protein isolate powder (SPI powder), and ground soy protein isolate from heat-pressed films (SPI film).

study. They also continued to increase their protein intake during the study. The effect of diets containing suboptimal concentrations of protein can result in the immediate response of decreased food intake [19]. Possibly due to this phenomenon or due to their loss of appetite in the second week, the rats fed the corn zein diets decreased their protein intake, by decreasing their total food intake.

Protein efficiency ratio and net protein ratio was determined at both 14- and 28-days (Table 5, Figures 1 and 2). The PER values for the corn zein powder and heat-set corn zein film were negative in the 14-day PER due to the loss of weight of the test animals during that period. The NPR values for corn zein powder and heat- set corn zein film were positive, however, because the protein-free treatment group lost more weight during that same period. Soy protein isolate PER and NPR values were slightly lower than expected. There is relatively no difference between the soy protein isolate powder and the soy protein isolate heat-set film for the PER and NPR.

Heat processing of soy protein isolate denatures the protein and increases the nutritive value. Raw soy protein isolates contain sufficient levels of trypsin-inhibiting activity to cause significant pancreatic hypertrophy in rats. During heat processing, the trypsin inhibitor of soy protein isolate is inactivated. The soy protein isolate used in this study was heat-processed during preparation. Thus, 
Table 5. PER and NPR at 14- and 28-days for in vivo assay sample diets.

\begin{tabular}{ccccc}
\hline Sample Diet & 14-Day PER & 28-Day PER & 14-Day NPR & 28-Day NPR \\
\hline Control & $2.40 \pm 0.06^{\mathrm{a}}$ & $2.17 \pm 0.06^{\mathrm{b}}$ & $2.73 \pm 0.08^{\mathrm{a}}$ & $2.32 \pm 0.08^{\mathrm{b}}$ \\
Corn Zein Powder & $-0.51 \pm 0.06^{\mathrm{e}}$ & - & $0.27 \pm 0.08^{\mathrm{e}}$ & - \\
Corn Zein Film & $-0.52 \pm 0.06^{\mathrm{e}}$ & - & $0.42 \pm 0.08^{\mathrm{e}}$ & - \\
SPI Powder & $1.56 \pm 0.06^{\mathrm{cd}}$ & $1.45 \pm 0.06^{\mathrm{d}}$ & $1.96 \pm 0.08^{\mathrm{c}}$ & $1.64 \pm 0.08^{\mathrm{d}}$ \\
SPI Film & $1.63 \pm 0.06^{\mathrm{c}}$ & $1.47 \pm 0.06^{\mathrm{cd}}$ & $2.01 \pm 0.08^{\mathrm{c}}$ & $1.65 \pm 0.08^{\mathrm{d}}$ \\
\hline
\end{tabular}

${ }^{\mathrm{a}-\mathrm{e}}$ Means with different superscripts are significantly different $(P<0.05)$ for either PER or NPR.

Table 6. Weekly faecal nitrogen output for each treatment group.

\begin{tabular}{|c|c|c|c|c|}
\hline \multirow{2}{*}{ Sample Diet } & \multicolumn{4}{|c|}{ \% Nitrogen } \\
\hline & Week 1 & Week 2 & Week 3 & Week 4 \\
\hline Protein Free & $1.24 \pm 0.11^{\mathrm{f}}$ & $1.27 \pm 0.11^{\mathrm{f}}$ & - & - \\
\hline Control & $1.51 \pm 0.12^{\mathrm{ef}}$ & $1.66 \pm 0.13^{\mathrm{e}}$ & $1.88 \pm 0.11^{\text {de }}$ & $1.65 \pm 0.11^{\mathrm{e}}$ \\
\hline Zein Powder & $4.64 \pm 0.10^{\mathrm{b}}$ & $4.84 \pm 0.11^{\mathrm{b}}$ & - & - \\
\hline Zein Film & $5.82 \pm 0.14^{\mathrm{a}}$ & $6.09 \pm 0.12^{\mathrm{a}}$ & - & - \\
\hline SPI Powder & $2.04 \pm 0.11^{\mathrm{c}}$ & $2.14 \pm 0.13^{c}$ & $2.01 \pm 0.12^{\mathrm{c}}$ & $2.15 \pm 0.12^{\mathrm{c}}$ \\
\hline \multirow[t]{2}{*}{ SPI Film } & $1.96 \pm 0.12^{\mathrm{cd}}$ & $1.90 \pm 0.12^{\text {cd }}$ & $1.91 \pm 0.11^{\text {cd }}$ & $1.97 \pm 0.11^{\mathrm{cd}}$ \\
\hline & \multicolumn{4}{|c|}{ \% Protein } \\
\hline Protein Free & $7.73 \pm 0.67^{\mathrm{h}}$ & $7.93 \pm 0.70^{\mathrm{h}}$ & - & - \\
\hline Control & $9.65 \pm 0.67^{\mathrm{ef}}$ & $10.59 \pm 0.68^{\mathrm{fh}}$ & $10.73 \pm 0.66^{\mathrm{de}}$ & $10.53 \pm 0.65^{\mathrm{de}}$ \\
\hline Zein Powder & $29.03 \pm 0.68^{\mathrm{b}}$ & $30.27 \pm 0.69^{b}$ & - & - \\
\hline Zein Film & $36.39 \pm 0.69^{a}$ & $38.05 \pm 0.7^{\mathrm{a}}$ & - & - \\
\hline SPI Powder & $12.73 \pm 0.67^{c}$ & $13.41 \pm 0.68^{\mathrm{c}}$ & $13.16 \pm 0.67^{\mathrm{c}}$ & $13.47 \pm 0.68^{\mathrm{c}}$ \\
\hline SPI Film & $12.26 \pm 0.68^{\mathrm{cd}}$ & $11.81 \pm 0.67^{\mathrm{cd}}$ & $11.88 \pm 0.69^{\mathrm{cd}}$ & $12.31 \pm 0.68^{\mathrm{cd}}$ \\
\hline
\end{tabular}

${ }^{\mathrm{a}-\mathrm{h}}$ Means with different superscripts are significantly different $(P \leq 0.05)$ for either \% nitrogen or \% protein; “-” indicates that no data was available for these weeks.

the soy protein isolate powder should have inactivated the trypsin-inhibitor.

The control group and protein-free group produced the least amount of nitrogen in the feces (Table 6). The corn zein treatment groups produced the most nitrogen in the feces. This could be a combined result of the rat's inability to digest either form of corn zein. The excess nitrogen could be from sloughed cells in the gut and/or non-protein nitrogen. This could also explain the positive nitrogen values in the protein-free treatment group. This group received no protein in their diet, but excreted obligatory nitrogen from cell gut secretions in their feces. The soy protein isolate groups released faecal nitrogen in quantities between $1.9 \%$ and $2.15 \%$.

\section{Conclusions}

It can be concluded from the in vitro digestibility assay that non-heat-set corn zein is slightly more digestible than heat-set corn zein film. SDS-PAGE results and free amino acid analysis verify this conclusion. An interaction between the protein and the plasticizer during film formation could inhibit the digestion of the protein by increasing bonding. The in vivo assay concluded that the soy protein isolate films were as digestible as the nonheat-set soy protein isolate powder. Using only 14-day NPR and PER data, it can also be concluded that the corn zein powder and heat-set corn zein films are equally digestible in vivo.

\section{REFERENCES}

[1] A. H. Brandenburg, C. L. Weller and R. F. Testin, "Edible Films and Coatings from Soy Protein," Journal of Food Science, Vol. 58, No. 5, 1993, pp. 1086-1089. doi:10.1111/j.1365-2621.1993.tb06120.x 
[2] J. M. Krochta, "Protein-Based Films and Coatings," CRC Press, Bocan Raton, 2002.

[3] A. Gennadios and C. L. Weller, "Edible Films and Coatings from Wheat and Corn Proteins," Food Technology, Vol. 44, No. 10, 1990, pp. 63-69.

[4] P. Cunningham, A. A. Ogale, P. L. Dawson and J. C. Acton, "Thermal Processing and Tensile Properties of Soy Protein Isolate Films,” Journal of Food Science, Vol. 65, No. 4, 2000, pp. 668-671. doi:10.1111/j.1365-2621.2000.tb16070.x

[5] C. Andres, "Natural Edible Coating Has Excellent Moisture and Grease Barrier Properties," Food Processing, Vol. 45, No. 13, 1984, pp. 48-49.

[6] R. C. Baker, J. M. Darfler and D. V. Vadehra, "Prebrowned Fried Chicken. 2. Evaluation of Predust Materials,” Poultry Science, Vol. 51, No. 4, 1972, pp. 12201222.

[7] H. R. Bolin, "Texture and Crystallization Control in Raisins,” Journal of Food Science, Vol. 41, No. 6, 1976, pp. 1316-1319. doi:10.1111/j.1365-2621.1976.tb01161.x

[8] G. G. Watters and J. E. Brekke, "Stabilized Raisins for Dry Cereal Products,” Food Technology, Vol. 15, 1961, pp. 236-238.

[9] M. S. Cole, "Method for Coating Dehydrated Food," US patent 3479191, 1969.

[10] “AOAC Official Methods of Analysis," 14th Edition, Association of Official Analytical Chemists, Washington DC, 1984.

[11] J. M. McLauglan, H. G. Anderson, L. Hackler, C. D. Hill,
R. G. Jansen, O. K. Murray, G. Sarwar and W. F. Sosulski, "Assessment of Rat Growth Methods for Estimating Protein Quality: Interlaboratory Study," Journal of the Association of Official Analytical Chemists, Vol. 63, No. 3, 1998, pp. 462-467.

[12] G. W. Padua and Q. Wang, "Protein-Based Films and Coatings,” CRC Press, Bocan Raton, 2002.

[13] S. Moore and W. H. Stein, "Methods in Enzymology," Academic Press, New York, 1963.

[14] T. E. Hugli and S. Moore, "Determination of the Tryptophan Content of Protein by Ion Exchange Chromatography of Alkaline Hydrolysates," Journal of Biological Chemistry, Vol. 24, No. 9, 1972, pp. 2828-2834.

[15] S. Moore, "On the Determination of Cystine as Cysteic Acid,” Journal of Biological Chemistry, Vol. 238, No. 1, 1963, pp. 235-237.

[16] Statistical Analysis System (SAS), 2008, Cary, NC.

[17] L. A. Heldman, T. C. Jenkins, J. C. Acton and M. E. Kunkel, "Digestibility of Protein from Powdered Supplements,” M.S. Thesis, Clemson University, Clemson, 1995.

[18] T. E. Creighton, "Proteins: Structures and Molecular Properties," W. H. Freeman and Company, New York, 1993.

[19] A. E. Harper, N. J. Benevenga and R. M. Wohlhueter, "Effects of Ingestion of Disproportionate Amounts of Amino Acids,” Physiology Review, Vol. 50, No. 3, 1970, pp. 428-558. 